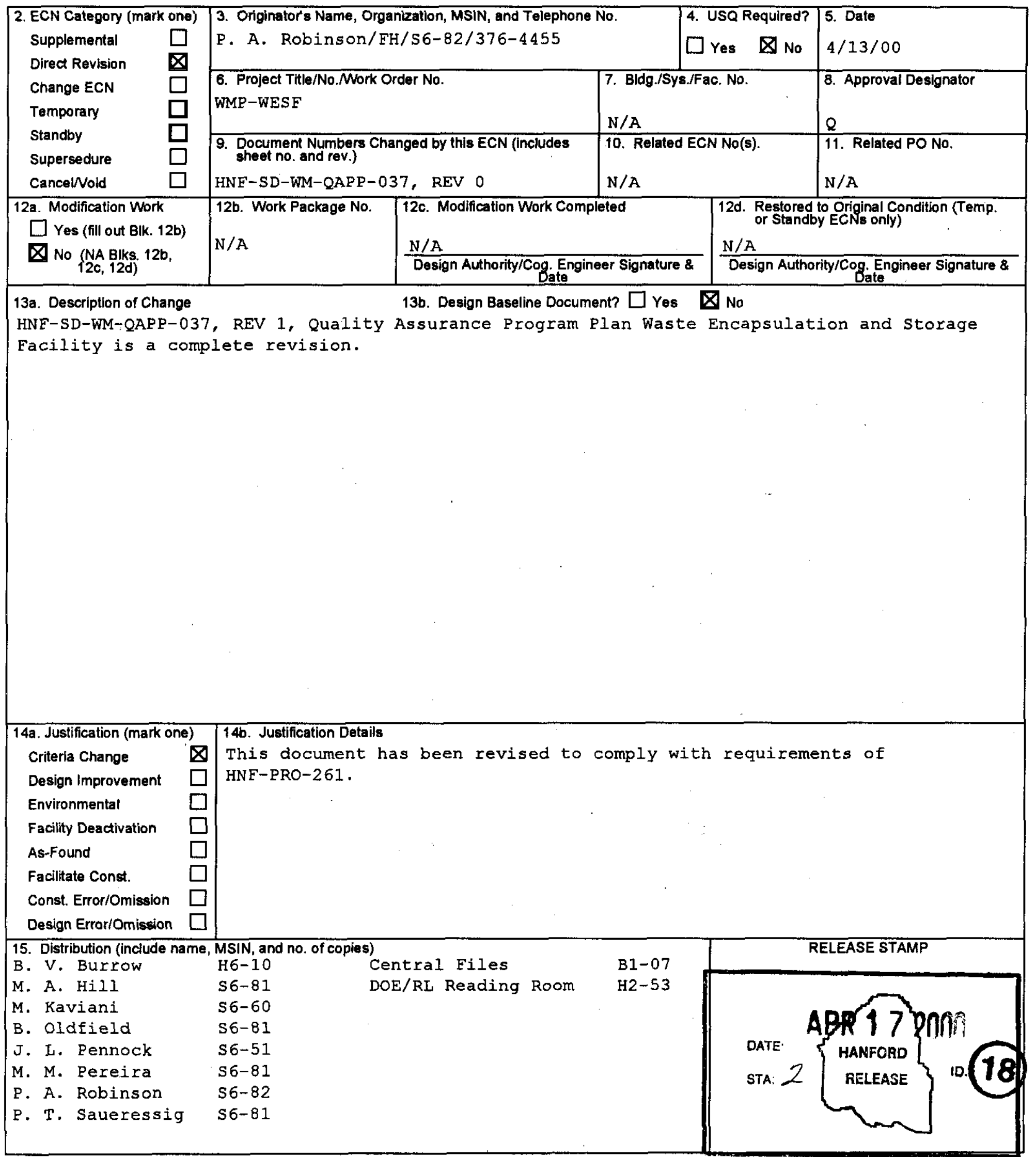




\section{ENGINEERING CHANGE NOTICE}

16. Design Verification

Required

[Yes

$\triangle$ No
ENGINEERING

Additional $\square$

Savings $\square$ s
Page 2 of 2

ECN (use no. from pg. 1)

658242

18. Schedule Impact (days)

CONSTRUCTION

Additional $\square \leqslant \mathrm{N} / \mathrm{A}$

Savings $\square$ \$

N/A

improvement $\square$ N/A
Delay

19. Change Impact Review: Indicate the related documents (other than the engineering documents identified on Side 1) that will be affected by the change described in Block 13. Enter the affected document number in Block 20.

SDD/DD

Functional Design Criteria

Operating Specification

Criticality Specification

Conceptual Design Report

Equipment Spec.

Const. Spec.

Procurement Spec.

Vendor information

OM Manual

FSAR/SAR

Safety Equipment List

Radlation Work Permit

Environmental Impact Statement

Environmental Report

Environmental Permit $\square$
$\square$
$\square$
$\square$
$\square$
$\square$
$\square$
$\square$
$\square$
$\square$
$\square$
$\square$
$\square$
$\square$
$\square$
$\square$
Seismic/Stress Analysis

Stress/Design Report

Interface Control Drawing

Calibration Procedure

Installation Procedure

Maintenance Procedure

Engineering Procedure

Operating Instruction

Operating Procedure

Operational Safety Requirement

IEFD Drawing

Cell Arrangement Drawing

Essential Material Specification

Fac. Proc. Samp. Schedule

Inspection Plan

Inventory Adjustment Request $\square \quad$ Tank Calibration Manual

Health Physics Procedure

Spares Multiple Unit Listing

Test Procedures/Specification

Component Index

ASME Coded Item

Human Factor Consideration

Computer Software

Electric Circult Schedule

ICRS Procedure

Process Control Manual/Plan

Process Flow Chart

Purchase Requisition

Tickler File

FSP-WESF-001, $\mathrm{QA}-2$

20. Other Affected Documents: (NOTE: Documents listed below will not be revised by this ECN.) Signatures below indicate that the signing organization has been notified of other affected documents listed below.

$$
\text { Document Number/Revision Document Number/Revision }
$$

Document Number/Revision

N/A

\section{Approvals}

Signature

Date

Design Authority $N / A$

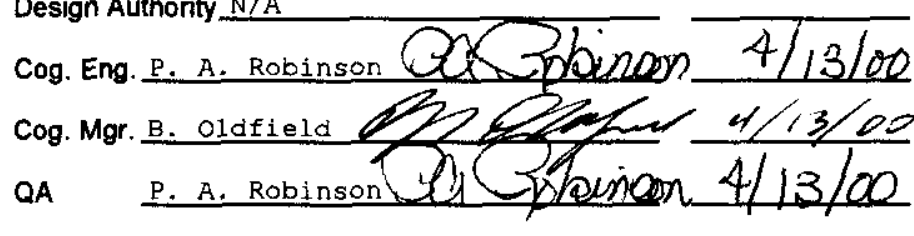

Safety

$N / A$

Environ. $\mathrm{N} / \mathrm{A}$

Other

N/A

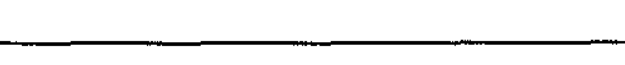

$\longrightarrow$




\section{QUALITY ASSURANCE PROGRAM PLAN WASTE ENCAPSULATION AND STORAGE FACILITY}

Prepared for the U.S. Department of Energy

Assistant Secretary for Environmental Management

Project Hanford Management Contractor for the

U.S. Department of Energy under Contract DE-ACO6-96RL13200

Fluor Hanford

P.O. Box 1000

Richland, Washington 


\title{
QUALITY ASSURANCE PROGRAM PLAN WASTE ENCAPSULATION AND STORAGE FACILITY
}

\author{
P. A. Robinson
}

Fluor Hanford

Date Published

April 2000

Prepared for the U.S. Department of Energy

Assistant Secretary for Environmental Management

Project Hanford Management Contractor for the

U.S. Department of Energy under Contract DE-AC06-96RL13200

Fluor Hanford

P.O. Box 1000

Richland, Washington
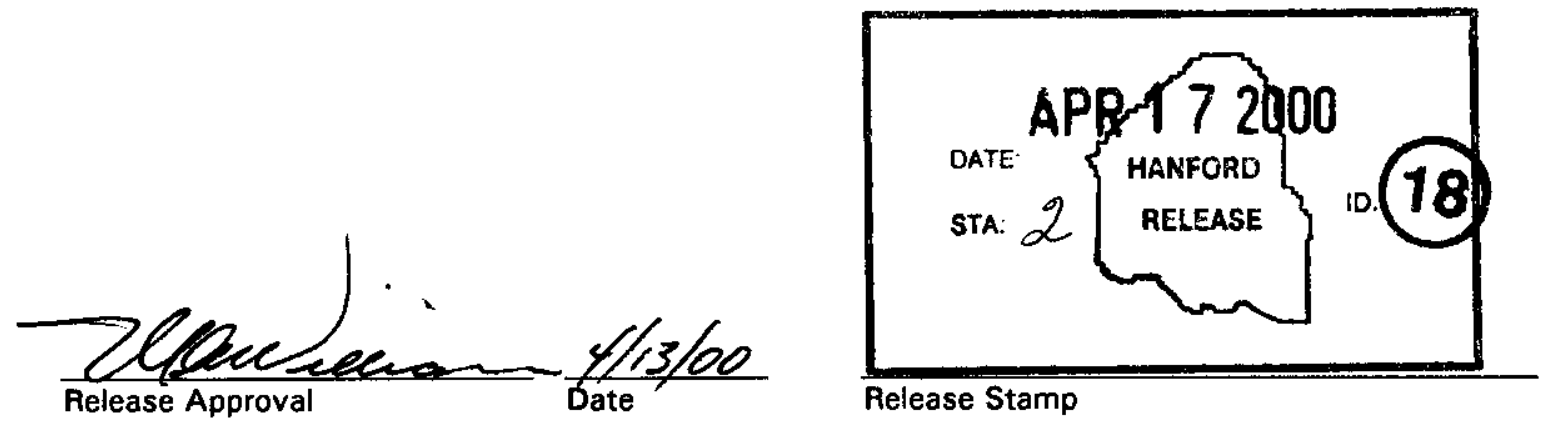
LEGAL DISCLAIMER

This report was prepared as an account of work sponsored by an agency of the United States Government. Neither the United States Government nor any agency thereof, nor any of their employees, nor any of their contractors, subcontractors or their employees, makes any warranty, express or implied, or assumes any legal liability or responsibility for the accuracy, completeness, or any third party's use or the results of such use of any information, apparatus, product, or process disclosed, or represents that its use would not infringe privately owned rights. Reference herein to any specific commercial product, process, or service by trade name, trademark,

manufacturer, or otherwise, does not necessarily constitute or imply its endorsement, recommendation, or favoring by the United States Government or any agency thereof or its contractors or subcontractors. The views and opinions of authors expressed herein do not necessarily state or reflect those of the United States Government or any agency thereof.

This report has been reproduced from the best avallable copy.

Printed in the United States of Amorica

Total Pages: 26 
RECORD OF REVISION

(2) Title

QUALITY ASSURANCE PROGRAM PLAN

WASTE ENCAPSULATION AND STORAGE FACILITY

Change Control Record
(3) Revision
(1) Document Number

HNE-SD-WM-QAPP-037
Page 1

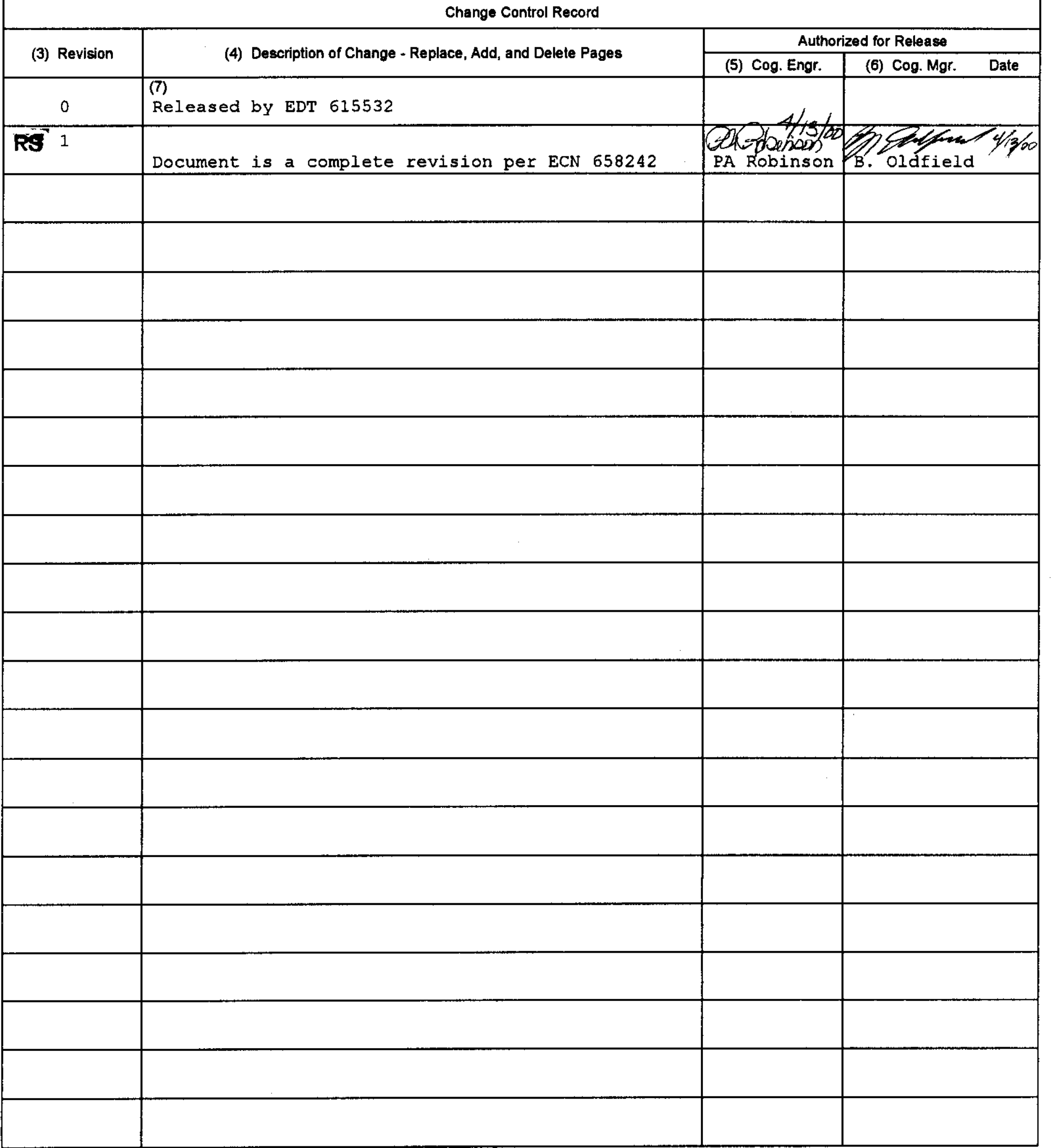




\section{Project Hanford Management Contract}

\section{QUALITY ASSURANCE PROGRAM PLAN}

\section{WASTE ENCAPSULATION and STORAGE FACILITY}

HNF-SD-WM-QAPP-037

Revision 1

Fluor Hanford

March 2,2000 


\title{
FLUOR HANFORD
}

\author{
WASTE MANAGEMENT PROJECT
}

\section{WASTE ENCAPSULATION and STORAGE FACILITY}

\author{
QUALITY ASSURANCE PROGRAM PLAN
}

\section{HNF-SD-WM-QAPP-037}

Revision 1

$\frac{\text { E. S. Aromi, Vice President }}{\text { Date }}$

Waste Management Project

Fluor Hanford

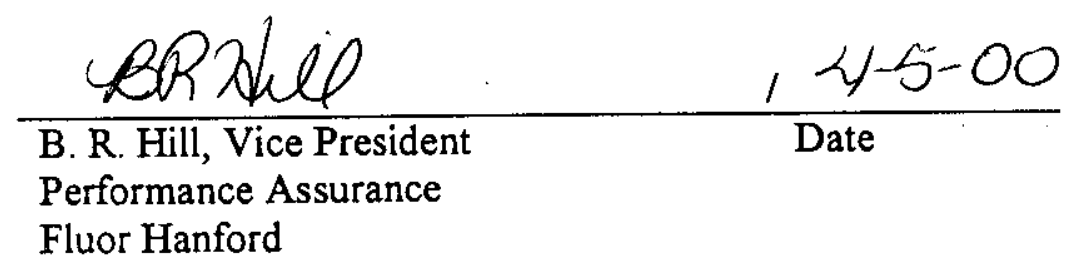




\title{
FLUOR HANFORD
}

\section{WASTE MANAGEMENT PROJECT}

\section{WASTE ENCAPSULATION and STORAGE FACILITY}

\author{
QUALITY ASSURANCE PROGRAM PLAN
}

\section{HNF-SD-WM-QAPP-037}

Revision 1

$\frac{\rho K H_{i m s}^{\prime}}{\text { C. K. Girres, Acting }}$

WMP Performance Assurance

Fluor Hanford

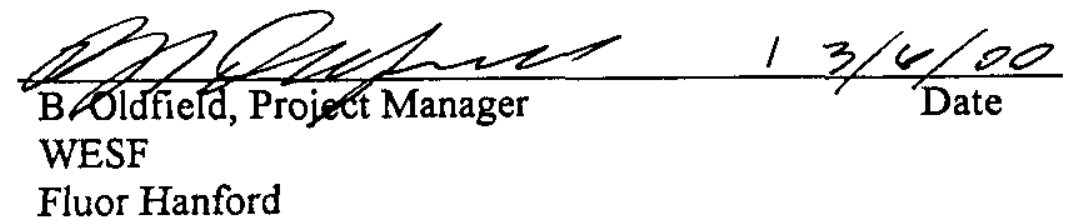




\section{Table of Contents}

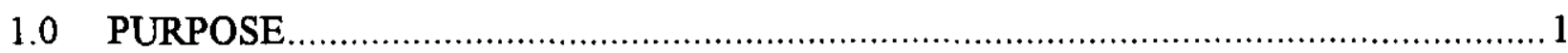

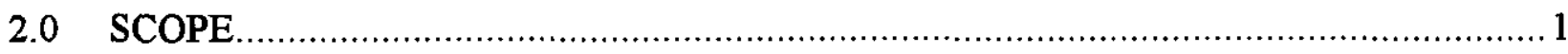

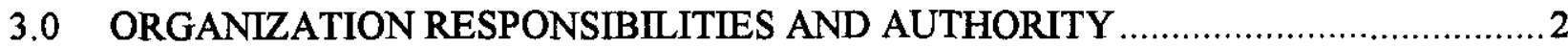

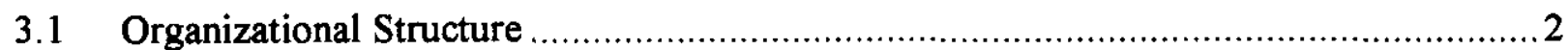

3.2 Responsibilities and Authority ................................................................. 2

3.2.1 Waste Management Project Employees........................................................ 2

3.2.2 The Vice President, Waste Management Project ............................................. 2

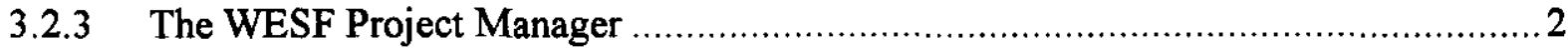

3.2.4 WESF Project Management Team ................................................................... 3

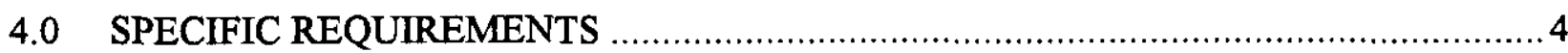

4.1 Quality Assurance Requirements Flowdown ................................................ 4

4.2 Waste Encapsulation and Storage Facility, Waste Management Project...................... 4

4.3 Application of the Graded Approach ................................................................. 5

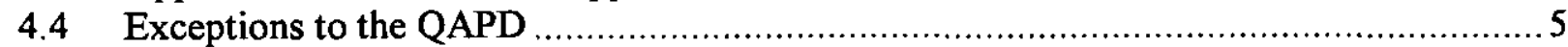

4.5 Management Systems Not Defined by the QAPD .......................................... 5

4.6 QAPD Implementation Matrix ............................................................... 5

4.7 Critical Characteristics of Products and Activities and Safety Classification................ 5

5.0 QUALITY ASSURANCE PROGRAM REQUIREMENTS ................................ 6

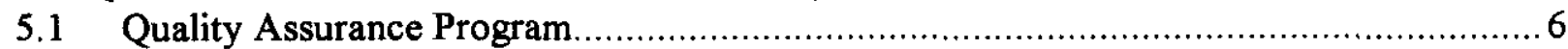

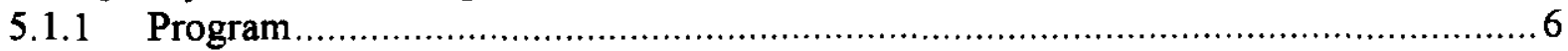

5.1.2 Personnel Training and Qualification ..................................................... 6

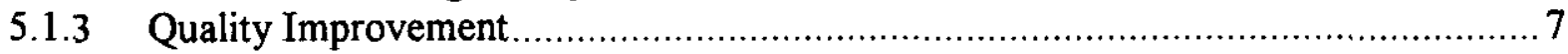

5.1.4 Document and Record Control ..................................................................... 8

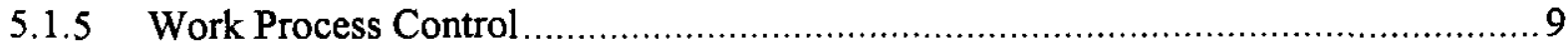

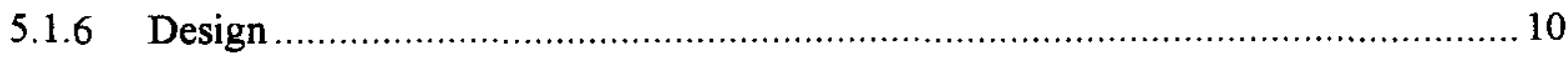

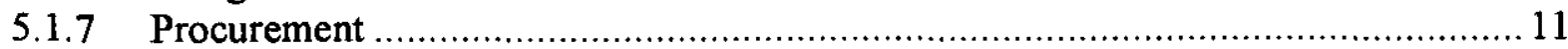

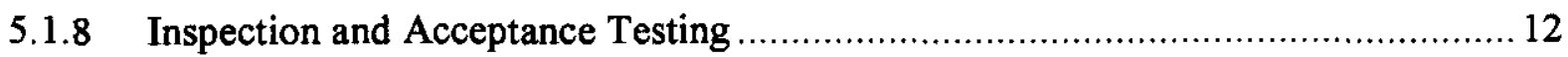

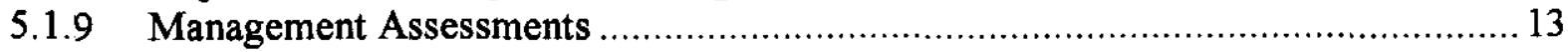

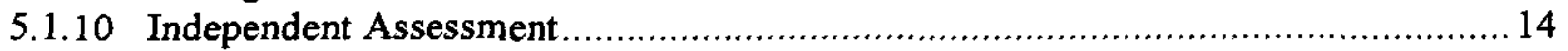

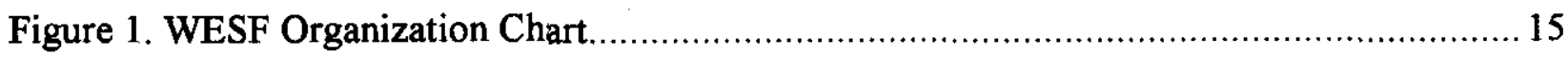

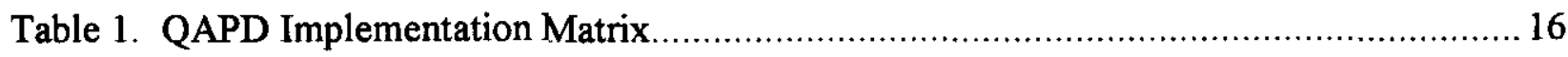




\subsection{PURPOSE}

This Quality Assurance Plan describes how the Waste Encapsulation and Storage Facility (WESF) implements the quality assurance (QA) requirements of the Quality Assurance Program Description (QAPD) (HNF-MP-599) for Project Hanford activities and products.

This QAPP also describes the organizational structure necessary to successfully implement the program. The QAPP provides a road map of applicable Project Hanford Management System Procedures, and facility specific procedures, that may be utilized by WESF to implement the requirements of the QAPD.

\subsection{SCOPE}

This QA Program Plan applies to tasks that are important and significant to safety or quality of WESF activities. Adherence to the Quality Assurance Program ensures the following:

- U. S. Department of Energy missions and objectives are effectively accomplished.

- Products and services are safe, reliable, and meet or exceed the requirements and expectations of the user.

- Hazards to the public, to Hanford Site and facility workers, and to the environment are minimized.

The format of this QAPP is structured to parallel that of 10 CFR 830.120, "Quality Assurance Requirements."

WESF's mission is to provide safe, cost-effective storage and management of the encapsulated radioactive materials inventory (601 $\mathrm{Sr}$ and $1335 \mathrm{Cs}$ capsules) at WESF until capsule disposition is determined and implemented.

Storing the capsules requires pool storage water to be maintained at specified levels to protect the facility worker from high radiation exposure and within water purity parameters to protect the capsule materials from corrosion. The capsules are monitored closely to ensure that critical process parameters are maintained and that early warnings of potential capsule problems are detected and mitigated to the extent possible. In the event of potential capsule problems (e.g., leaks and swellings), capsules are capable of being removed from the pool cell storage area to a series of remote handled "hot cells" where inspection, testing, and other capsule handling activities can be conducted. While not normally done, the capsules can be loaded into transportation casks for transport to other facilities or can be received from other facilities (via transportation casks) and placed back into storage within the hot cell or pool cell areas. 
WESF activities are defined in the Multi-Year Work Plan (MYWP) (HNF-SP-1234) and Project Baseline Summary RL-TP02. WESF's scope of work will change periodically and will be defined annually in the MYWP.

Fluor Hanford $(\mathrm{FH})$ has responsibilities relative to the quality management and other processes related to WESF activities. These systems and processes are outlined in the PHMC QAPD, HNF-MP-599.

\subsection{ORGANIZATION, RESPONSIBILITIES AND AUTHORITY}

\subsection{Organizational Structure}

The structure, interfaces, functional responsibilities and levels of authority established for the Project Hanford Management Contract (PHMC) organization are defined in the QAPD, Part 1, Section 1, and in the PHMC Management and Integration Plan (HNF-MP001).

The Waste Management Project (WMP) organizational structure, with its lines of communication and authorities, is presented in HNF-SD-WM-QAPP-036.

WESF is a part of the Waste Management Project. The organizational structure, with lines of communications and authorities, is shown in Figure 1.

\subsection{Responsibilities and Authority}

\subsubsection{Waste Management Project Employees}

The achievement of quality in all activities is the responsibility of all WMP personnel.

\subsubsection{Vice President, Waste Management Project}

The Vice President, Waste Management Project, is responsible for establishing the Quality Assurance Policy for the WMP and for the scope and implementation of the WESF QA Program, including the approval of the WESF QAPP.

\subsubsection{WESF Project Manager}

The WESF Project Manager reports to the Vice President, Waste Management Project, and has overall responsibility for the WESF QA program and leads the WESF organization in implementation of the WESF QAPP. The WESF Project Manager ensures that WESF achieves its goals of continuous process improvement and personnel 
development. In addition, the WESF Project Manager is responsible for ensuring that WESF is operated and maintained within the bounds of the Authorization Basis to assure the safe storage of cesium and strontium capsules and is responsible for:

Establishing, maintaining, and approving the WESF Quality Assurance Program Plans (QAPPs) as needed to describe how the Project Hanford QA program is implemented for WESF's scope of work and to facilitate incorporation of $\mathrm{FH}$, facility, and project-specific requirements.

Ensuring that applicable requirements of the Project Hanford QA Program and WESF's own QAPP are contractually imposed upon contractors, and suppliers.

Approving QAPPs developed for WESF related tasks.

Ensuring Project Hanford procedures applicable to WESF activities are used and any additional internal procedures or instructions needed to implement WESF QA programrelated activities are developed.

Ensuring that the WESF Project Management Team identifies subcontractors and suppliers that need to be added to the Evaluated Supplier's List (ESL) are identified to FH Performance Assurance (PA).

Reporting on the effectiveness of the QA program.

Promptly identifying and correcting conditions that are adverse to quality.

Ensuring that management assessments are performed.

Providing individuals with the training and support to implement this program.

\subsubsection{WESF Project Management Team}

Supporting the WESF Project Manager is the WESF Project Management Team. For the areas managed, the WESF Project Management Team is responsible for the following:

Reviewing the QAPP for accuracy and completeness prior to approval by the WESF Project Manager.

Ensuring that the QAPP is understood by personnel within the managed organization.

Developing and implementing project management plans, program plans, and supporting quality documents, as appropriate, for the organization managed. Project management plans, program plans, and other quality documents shall implement the WESF QAPP.

Contractually imposing the applicable requirements of the Project Hanford QA Program and WESF's own QAPP on contractors, and suppliers. 
Ensuring QAPPs are developed for WESF related tasks.

Using Project Hanford procedures applicable to WESF activities and developing any additional internal procedures or instructions needed to implement WESF QA programrelated activities.

Identifying to FH PA any subcontractors and suppliers that need to be added to the ESL and providing funding of activities related to vendor evaluations.

Assessing the program to improve processes and determine their effectiveness.

Identifying and correcting problems found that affect quality performance.

Providing individuals, within their organizations, the information, training, support and other resources necessary to perform their duties in a quality manner.

\subsection{SPECIFIC REQUIREMENTS}

10 CFR 830.120 is the source document for the WESF quality assurance program. HNFMP-599, Project Hanford Quality Assurance Program Description, defines the quality assurance program and the measures to achieve 10 CFR 830.120 compliance. HNF-MP599 has been issued by Fluor Hanford (FH) and approved by the U. S. Department of Energy. A standards/requirements identification document (S/RID) for WESF (HNF-SDMP-SRID-WESF-007) lists specific codes, standards, and requirements used at the facility to implement the quality assurance program.

Other PHMC team members may be responsible for portions of the quality assurance program (e.g., supplier evaluation and training of inspection personnel are the responsibility of FH PA). Refer to section 1, part 1 of the FH QAPD and HNF-MP-001, PHMC M\&I Plan, for details regarding those roles and responsibilities under the Project Hanford Management Contract.

\subsection{Quality Assurance Requirements Flowdown}

Applicable QA requirements are promulgated by WESF to contractors through procurement documents. Additionally, not all program activities are performed by WESF. Various activities such as site training, welding, NDE, procurement, and inspector qualification are performed by FH Project Hanford Integrator Functional Group or Service Providers.

\subsection{Waste Encapsulation and Storage Facility, Waste Management Project}

This QAPP describes the Waste Encapsulation and Storage Facility (WESF) organization and its relationship and responsibilities with the Waste Management Project 
HNF-SD-WM-QAPP-037, REV 1

\subsection{Application of the Graded Approach}

1. The WESF quality management program focuses on the controls and systems necessary to ensure the quality as required by 10 CFR 830.120. The quality controls and systems will be applied to WESF activities using a graded approach that complies with HNF-MP-599, Part 2, Section 1, 3.10. The graded application shall not be used to circumvent applicable QA, legal or contractual requirements.

Application of a graded approach is specified in several PHMC Management Plans (e.g., Integrated Safety and Health Management Systems Plan, HNF-MP-003, Configuration Management Plan, HNF-MP-013) and Project Hanford Management System functional area procedures (e.g., Maintenance Management, HNF-PRO-069; Engineering Design and Evaluation, HNF-PRO-097; Criticality Safety General Requirements, HNF-PRO334; Safety Analysis and Technical Safety Requirement, HNF-PRO-700; Pre-Job Safety Planning, HNF-PRO-079; and Hazard and Accident Analysis Process, HNF-PRO-704). Also, in some cases, these procedures identify recommended quality codes and standards applicable to the activity.

\subsection{Exceptions to the QAPD}

No exceptions are taken to the requirements established by the QAPD.

\subsection{Management Systems Not Defined by the QAPD}

No additional management systems other than those defined in the QAPD are utilized.

\subsection{QAPD Implementation Matrix}

The implementation matrix (Table 1) provides a roadmap from HNF-MP-599 (QAPD) requirements to selected PHMC and WESF procedures which may be utilized as part of the WESF QAPP to perform some work activities. Application of specific procedures is based upon the type of work being performed and the safety significance of the work.

\subsection{Critical Characteristics of Products and Activities and Safety Classification}

Hazard and accident analysis is used to select the set of design features and controls WESF relies on to mitigate the frequency or consequences of identified hazardous conditions, based upon their importance and significance to safety. The design features selected are designated as safety structures, systems and components (SSCs) and include safety class and safety significant SSCs. The operation controls selected are documented in the WESF safety equipment list (SEL) (HNF-SD-WM-SEL-008) that identifies critical SSCs that are important to the nuclear safety function in the facility. The SEL is based on the WESF Basis for Interim Operation (BIO), (HNF-SD-WM-BIO-002). 
HNF-SD-WM-QAPP-037, REV 1

\subsection{QUALITY ASSURANCE PROGRAM REQUIREMENTS}

\subsection{Quality Assurance Program}

The WESF Quality Assurance Program is derived from the PHMC QAPD that implements 10 CFR 830.120 and DOE Order 414.1. The system includes the ten basic sections of the QAPD that forms the foundation for the requirements for all WESF quality assurance activities.

\subsubsection{Program}

A written quality assurance program (QAP) shall be developed, implemented, and maintained. The QAP shall describe the organizational structure, functional responsibilities, levels of authority, and interfaces for those managing, performing, and assessing quality affecting work. The QAP shall describe the management processes including planning, scheduling and resource considerations comprised of a hierarchy of documents, that has been established and is being maintained. This Quality Assurance Program Plan (QAPP) defines the Quality Assurance Program for WESF and complies with QAPD Part 2, Section 1, "Program."

\subsubsection{Personnel Training and Qualification}

The personnel training and qualification program has been established to ensure that WESF personnel are trained and qualified to perform assigned tasks. Training and qualification shall ensure that personnel are capable of performing assigned work, before they attempt that work. The training and qualification program provides for the development of personnel proficiency commensurate with the scope, complexity, and nature of an assigned activity. Management is responsible for developing generic staff position requirements based on the level of education and experience necessary for proficient performance of tasks related to a given staff position.

Training and indoctrination needs for personnel are identified and documented by management. Personnel are trained to perform assigned tasks in a manner that minimizes risk to themselves, coworkers, and the public; minimizes negative impacts to the environment; and minimizes risk of damage to the facility and equipment.

Training and indoctrination of personnel is performed to ensure proficiency is achieved and maintained. Continuing training is provided for personnel to maintain proficiency, as applicable to position requirements.

Instructors who are technically knowledgeable of the training subject matter conduct training. The effectiveness of training is evaluated and the results used for continuous improvement of training systems and processes. The bases for evaluation include feedback from trainees, assessment results, and trend analyses. 
HNF-SD-WM-QAPP-037, REV 1

Job function descriptions based on the work to be performed have been developed that describe minimum requirements for education and experience and physical condition and certification requirements, if required. Training and qualification requirements for job functions are periodically reviewed to ensure that they continue to reflect the correct systems, procedures, and policies applicable to each position.

Qualification and/or certification of personnel assigned to conduct inspection and/or activities for acceptance is documented.

Records are maintained to enable verification of personnel qualification and/or certifications and completion of required training.

The WESF training and personnel qualifications shall meet the requirements of the QAPD, Part 2, Section 2, "Personnel Training and Qualification."

\subsubsection{Quality Improvement}

The objective of quality improvement is to prevent problems and to continuously improve the quality of items and work processes. The basis to quality improvement is that (1) work activities can be planned, performed, assessed, and improved; and (2) lessons learned from this process can be used when planning subsequent activities. The focus of the quality improvement process is to reduce the variability of work processes that influence the quality of the product. Processes for identifying and reporting deficiencies are developed and implemented. Personnel are encouraged to identify potential areas for improvement.

Under the corrective action management program, organizations have the authority to identify quality problems and to initiate, recommend, or provide solutions through designated changes. Management systems (e.g., root cause analysis, lessons learned, etc.) are used to plan, implement, and evaluate improvements. Deficiencies are reported promptly. Deficiency identification, response, and action verification are documented and tracked in the PHMC-wide deficiency tracking system managed by FH.

Nonconforming items are controlled using documented and approved procedures to prevent their inadvertent installation or use. Responsibility for preventing the use, delivery, installation, or operation of nonconforming items is designated in procedures.

A nonconformance report, or other appropriate method, is used to notify affected organizations and to document the description, disposition, action, verification, and closure of identified nonconforming items.

Nonconforming items discovered during plant operations, maintenance, or modification are identified on a plant work request (W-110) for correction and are tracked by the Job Control System (JCS). Nonconformances that require investigation for cause and corrective action are documented on a Nonconformance Report (NCR) or in accordance with occurrence reporting procedures. 
Items, services, and processes that do not meet the established quality requirements are identified, controlled, and corrected as soon as practical in accordance with established priorities. Controls placed on nonconforming items prevent inadvertent installation of use through identification, documentation, evaluation, segregation (when applicable), and disposition of the items. The status of nonconforming items is tracked to closure. Personnel responsible for reviewing and dispositioning nonconformances have an adequate technical understanding of the items or activities involved and have access to pertinent information relative to the nonconformance.

Reworked items are reexamined in accordance with applicable procedures and with the original acceptance criteria. Repaired items are re-examined in accordance with the nonconforming item disposition acceptance criteria. Satisfactory completion of actions required by the nonconformance disposition is verified prior to closure.

Performance indicators (PIs) are developed and used to identify trends relative to quality performance. WESF management analyzes WESF-specific performance data for trends or other information useful for identifying opportunities to improve facility performance. Appropriate actions are taken when either adverse trends or improvement opportunities are identified. When an adverse trend is observed, cause analysis is performed to determine appropriate actions to reverse the trend.

The quality improvement processes established by WESF shall meet the requirements of the QAPD, Part 2, Section 3, "Quality Improvement."

\subsubsection{Document and Record Control}

Documents and records are in a form that can be controlled, protected, and retained for the required duration. The documents and records program establishes requirements for control of the preparation, review, approval, issuance, use, and revision to documents that establish policies, prescribe work, specify requirements, or establish design to assure that correct documents are employed. Controlled documents and revisions to those documents are reviewed for adequacy, completeness, and correctness before approval.

After approval, controlled documents are issued to specified users. The process for distribution of controlled documents ensures that the latest approved revisions are provided to personnel using these documents. Copies of superseded or cancelled controlled documents are identified and kept as records for their specified retention period.

Records are specified, identified, prepared, reviewed, approved, and maintained. Sufficient records are generated to accurately reflect completed work and demonstrate compliance with applicable requirements. Records that furnish documentary evidence of quality are prepared, maintained, and stored in accordance with approved procedures and instructions. Records must be legible, identifiable, accurate, complete, protected and retrievable. DOE 1324.a, Records Disposition, requires use of the records schedules 
HNF-SD-WM-QAPP-037, REV 1

published by the National Archives and Records Administration. These schedules define the retention periods of different document types.

Documents and records generated by WESF shall meet the requirements of the QAPD, Part 2, Section 4, "Documents and Records."

\subsubsection{Work Process Control}

Work processes are controlled by instructions, procedures, design documents, technical standards, or other means appropriate to the specific tasks to be performed. When applicable, work process documents are developed, reviewed, and approved by personnel technically knowledgeable of the work. The level of detail contained within work process documents is commensurate with the complexity of the specific tasks and risks associated with the work. Applicable work process documents are readily accessible to the worker. Proper work completion is documented and appropriate records maintained.

Processes that are highly dependent on process control or operator skill, and for which the quality of the product cannot be readily determined by inspection or test, are controlled as special processes. Examples are welding, brazing, and nondestructive examination.

Methods of item identification and administrative control are used to prevent the use of incorrect or defective items and to maintain traceability for those items in fabrication as required by specification, codes, and standards. Status indicators are used to indicate the operating status of systems and components (such as by tagging valves, switches or controls) to prevent inadvertent operation. When used, marking and labeling is not detrimental to the item.

Portable and installed instruments used for process monitoring or data collection are controlled, calibrated, and maintained, as appropriate.

Handling, storage, shipping, cleaning, and preservation of items are controlled to prevent damage, loss, or deterioration. Marking and labeling of items are maintained throughout packaging, shipping, handling, and storage. Special protective measures are specified and provided when required to maintain acceptable quality.

Computer software used in applications important to environmental, safety, health, and quality aspects of WESF activities is subject to appropriate controls throughout the software life cycle.

WESF implementing procedure shall meet the requirements of the QAPD, Part 2, Section 5, "Work Processes." 


\subsubsection{Design}

Design inputs include such information as technology decisions, design bases, health and safety considerations, environmental conditions and regulations, expected life cycle, performance parameters, codes and standards requirements, reliability requirements, safety classification, and existing structures/equipment interfaces.

Design inputs are identified and documented, and their selection is reviewed and approved by the responsible design organization to ensure that sound engineering/scientific principles and appropriate standards are being used. Design inputs are specified to a level of detail necessary to adequately support design decisions and design activity including design verification and evaluation of design changes. Changes from approved design inputs, including the reason for the changes, are identified, documented, approved by the responsible design organization, and controlled.

Design work, including changes, incorporates applicable requirements and design bases. The design process translates design input into design output documents that are technically correct and meet the end user's requirements. Design interfaces are identified, documented, and controlled throughout the design process. Aspects of design that are important to safety, reliability, or environmental considerations are identified during the design process. The final design is relatable to the design input in sufficient detail to permit design verification.

Design analyses are performed and documented in a planned and controlled manner. Design calculations are identified and documented so that the calculations are retrievable.

The organization accomplishing the design ensures that design output documents meet design-input requirements and are useable for their intended purpose. They verify that any deviations from applicable standards or requirements have been approved and documented.

Design verification methods include, but are not limited to, technical reviews, peer reviews, alternate calculations, and qualification testing. Engineering documents (e.g., drawings, specifications, design analyses, system descriptions, engineering studies, technical reports, etc.) are verified in accordance with approved procedures and instructions. The procedures identify the positions responsible for verification and require that design errors are identified and corrected. Documents cannot be released without verification. Verification of design documents is accomplished by individual or interdisciplinary design reviews, alternate calculations to verify the correctness of the original design calculations, or qualification testing to demonstrate adequacy of performance under conditions that simulate the most adverse design conditions. The extent of design verification is commensurate with the designed product's complexity and importance to safety, the environment, and project success. Design verification is performed by individuals or groups who were not directly involved in performing the design. 
Design changes, including field changes, are controlled by measures commensurate with those applied to the original design. These measures include assurance that the design analyses for the structure, system, or component is still valid. Design for temporary modifications receive the same level of control as the original design for permanent modifications.

Computer software used to originate or verify safety or other risk-significant design solutions during the design process is validated and the status of validation shall be identified and documented prior to use.

WESF projects shall implement the requirements of the QAPD, Part 2, Section 6, "Design."

\subsubsection{Procurement}

Procurement activities are planned and documented to ensure a systematic approach to the procurement process. Procurement planning is commensurate with the importance of the purchased item or service to the facility or process.

Procurement procedures ensure that regulatory requirements, design and site investigation bases, and other necessary quality requirements are included or referenced in the documents used for procurement of material, equipment, and services. Procurement documents covered in this section include purchase orders, purchase requisitions, task orders, statements of work, and store orders.

Procedures are in place for preparation, revision, review, approval, issue, control, and retention of procurement documents. These procedures specify the need to identify the requirements to be met by each supplier's quality assurance system in the instructions for submitting documents.

Measures are established to ensure that purchased material, equipment and services conform to the procurement documents. Established measures include provisions for source evaluation and selection, objective evidence of inspection at the contractor or subcontractor source, examination of products upon delivery, and assessments or audits. Documentary evidence that materials and equipment conform to code, regulation, or contract procurement requirements is made available before installation or before use.

The requirement for a documented quality assurance program is specified in applicable procurement documents and is invoked on the basis of the safety function of the items or services being procured. The extent of the documented supplier quality assurance program, when required, depends upon the type and use of the item or service being procured. Suppliers are selected based on an evaluation of their capability to provide items and services that meet the requirements listed in the procurement documents. Once selected, suppliers of the following items (except Commercial Grade Items, see 3.7) or services, at a minimum, shall be identified on the FH ESL. 
a) Items (i.e., structures, systems, and components) and services that provide safety function in a PHMC-managed facility.

b) Environmental analytical services.

The ESL is maintained by FH PA. Performance of approved suppliers is evaluated to ensure that they continue to provide acceptable items and services. Notes: On-site Hanford Contractors (OHCs) shall not be required to be on the FH ESL when their QA programs have been approved by DOE. Contractors providing direct support services used for staff augmentation shall work to their client's QA program, and need not be evaluated for placement on the FH ESL.

Procured items and services meet established requirements and perform as specified. Methods used to accept an item or service from suppliers may consist of one or more of the following:

- Supplier certification and release (Certificate of Conformance)

- Source verification or inspection

- Receiving inspection

- Acceptance testing

- Post-installation testing

Where the design utilizes commercial grade items (CGI) in SC or SS applications, the following requirements are an acceptable alternative to other requirements of this section:

- The CGI and its critical characteristics shall be identified by the cognizant design organization

- The acceptance method used for CGI shall be specified by the cognizant design organization and shall provide assurance that the items to be received will meet specified critical characteristics.

- Procurement documents shall indicate that the material or item is intended to be dedicated for use in a safety class or safety significant installation or application.

WESF procurement processes shall implement the requirements of the QAPD, Part 2, Section 7, "Procurement."

\subsubsection{Inspection and Acceptance Testing}

Procedures have been prepared that govern inspection and test planning associated with the application of the requirements of this section. The inspection and acceptance test requirements for structures, systems, and components are identified by the cognizant design organizations. Acceptance parameters and other inspection or test requirements are specified, or the appropriate sections of approved codes or standards referenced, as part of the design documentation and work planning process, and are included in work control documents. 
Inspections, surveillance, and testing of items and activities that have the potential to affect quality, and related procurements, constructions, repair, modifications, maintenance, and installation are subject to these requirements. Suppliers and contractors are expected to inspect and test their own work. Assessments are performed to ensure that these inspections and tests are adequately and competently performed. Inspection and acceptance criteria are derived from engineering design documents, supplier information, construction procedures, and maintenance procedures. As applicable to the task being performed, inspection procedures and instructions will identify the following:

- references to applicable documents such as drawings, specifications, and procedures;

- types of inspections to be performed;

- characteristics to be inspected;

- individuals or groups responsible for performing inspections;

- acceptance criteria (explicit or by reference) obtained from specifications, drawings, supplier instructions, and standards;

- description of the inspection method and equipment to be used, or reference to an appropriate procedure;

- documentation.

Inspections and tests are performed by technically qualified personnel who have the freedom of access to communicate with plant management to report inspection and test results. Inspections and tests are performed following approved written directions. Independent acceptance inspection, where required, is performed by an organization that is independent of the organization performing the work.

Inspection and test results are documented and conformance with acceptance criteria evaluated to ensure that requirements have been satisfied.

The status of inspection and test activities is identified either on the items or in documents traceable to the items to ensure that items that have not passed the required inspections and tests are controlled.

Measuring and Test Equipment (M\&TE) used in verifying conformance to requirements, monitoring processes, or collecting data is controlled, calibrated; and maintained.

WESF shall implement the requirements of the QAPD, Part 2, Section 8, "Inspection and Acceptance Testing."

\subsubsection{Management Assessments}

Periodic assessments of management systems and processes are planned, scheduled, and conducted. Management problems that hinder the organization from achieving its objectives are identified, tracked and corrected in accordance with the requirements in section 5.1.3, "Quality Improvement." 
WESF shall perform management assessments as required by QAPD, Part 2, Section 9 , "Management Assessments."

\subsubsection{Independent Assessment}

WESF management is responsible for cooperating with the $\mathrm{FH}$ independent assessment personnel in planning, preparation, and performance of assessments. WESF management is responsible for promptly correcting problems found by independent assessments and for ensuring corrective action is effective. 
跑

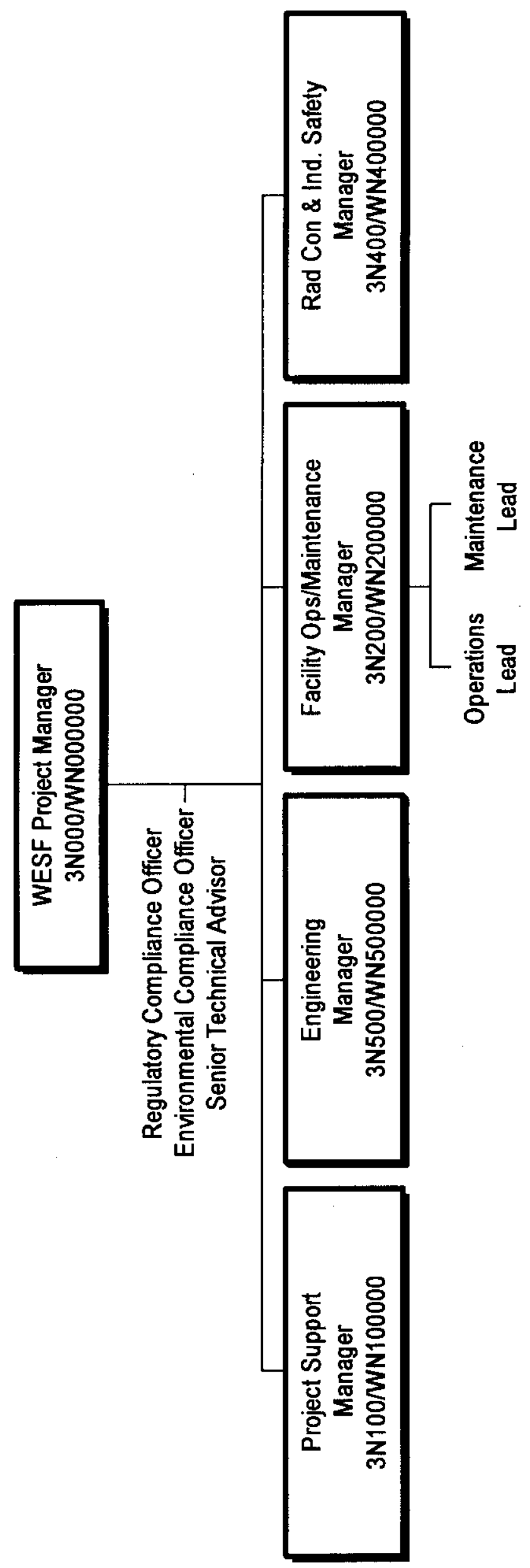


Table 1. QAPD Implementation Matrix

\begin{tabular}{|c|c|c|}
\hline \multicolumn{3}{|c|}{$\begin{array}{l}\text { WESF } \\
\text { HNF-MP-599, PHMC QAPD IMPLEMENTATION MATRIX } \\
\text { MARCH 2, } 2000\end{array}$} \\
\hline \multirow{2}{*}{$\begin{array}{l}\text { PROJECT HANFORD QAPD } \\
\text { PART } 2\end{array}$} & \multicolumn{2}{|l|}{ IMPLEMENTING PROCEDURES } \\
\hline & $\begin{array}{l}\text { PHMC-WIDE } \\
\text { PROCEDURES }\end{array}$ & $\begin{array}{l}\text { CONTRACTOR } \\
\text { PROCEDURES }\end{array}$ \\
\hline $\begin{array}{l}\text { SECTION 1, PROGRAM } \\
\text { - Quality Amurance Program Plans } \\
\text { - Project Hanford QA Requiremento Flowdown } \\
\text { - Quality Planning } \\
\text { - Organization, Responsibilities, and Interfaces } \\
\text { - Readiness Review } \\
\text { - Stop Work Authority } \\
\text { - Oraded Application of Project Hanford OA Program }\end{array}$ & 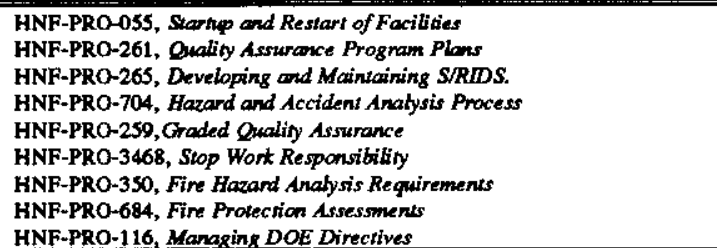 & $\begin{array}{l}\text { FSP-WESF-001, } \\
\text { Sections QA-1; MS-2; MS- } \\
\text { 3; MS-6; MS-11, EN-2, } \\
\text { OH-1; OH-9; RP-1; } \\
\text { FSP-WESF-002; Section } \\
1.0 \text {. }\end{array}$ \\
\hline $\begin{array}{l}\text { SECTION 2, PERSONNEL TRAINING AND } \\
\text { QUALIFICATION } \\
\text { - Project Hanford Training and Qualification Program } \\
\text { - Training and Indoctrination } \\
\text { - Qualification and Certification } \\
\text { - Training and Quadification Records }\end{array}$ & 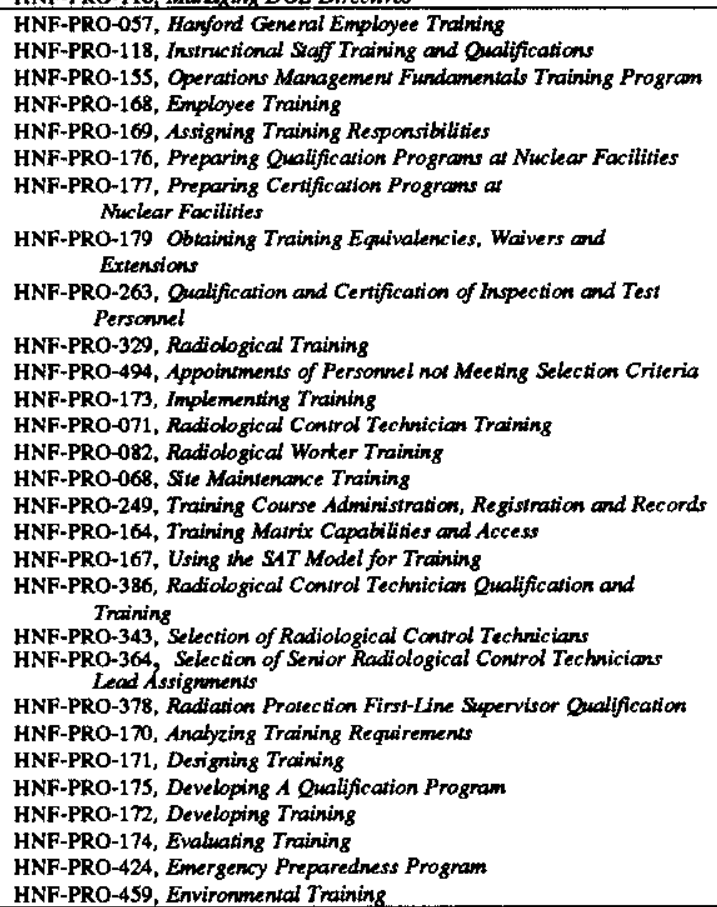 & $\begin{array}{l}\text { FSP-WESF-001, } \\
\text { TN-1 } \\
\text { HNF-2912 }\end{array}$ \\
\hline
\end{tabular}




\section{WESF}

HNF-MP-599, PHMC QAPD IMPLEMENTATION MATRIX

MARCH 2, 2000

\begin{tabular}{|c|c|c|}
\hline \multirow{2}{*}{$\begin{array}{l}\text { PROJECT HANFORD QAPD } \\
\text { PART } 2\end{array}$} & \multicolumn{2}{|l|}{ IMPLEMENTING PROCEDURES } \\
\hline & $\begin{array}{l}\text { PHMC-WIDE } \\
\text { PROCEDURES }\end{array}$ & $\begin{array}{l}\text { CONTRACTOR } \\
\text { PROCEDURES }\end{array}$ \\
\hline $\begin{array}{l}\text { SECTION 3, QUALITY IMPROVEMENT } \\
\text { - Deficiency Identification } \\
\text { - Corrective Action Management } \\
\text { - Nonconformance Control } \\
\text { - Performance Data Aralysis }\end{array}$ & 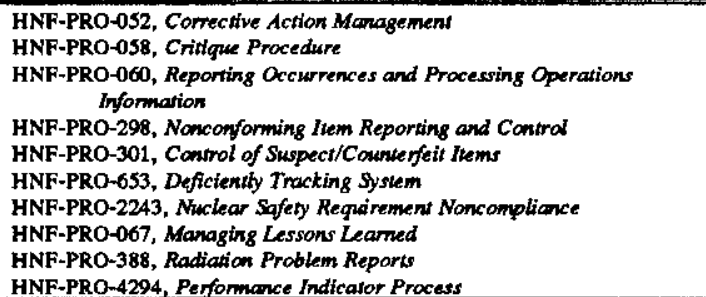 & $\begin{array}{l}\text { FSP-WESF-001, Sections } \\
\text { QA-2; QA-3; MS-7; } \\
\text { FSP-WESF-002, Sections } \\
\text { 1.1. } 6.0 \text {. }\end{array}$ \\
\hline $\begin{array}{l}\text { SECTION 4, DOCUMENTS AND RECORDS } \\
\text { - Documents } \\
\text { - Records }\end{array}$ & $\begin{array}{l}\text { HNF-PRO-210, Records Management Program Standands } \\
\text { HNF-PRO-222, Quality Assurance Reconds Standands } \\
\text { HNF-PRO-224, Docroment Control Program Standards } \\
\text { HNF-PRO-233, Review and Approval of Docwments } \\
\text { HNF-PRO-589, Processing Project Hanford Procedures } \\
\text { HNF-PRO-604, Hanford Document Numbering System } \\
\text { HNF-PRO-112, Forms Administrative Standands } \\
\text { HNF-PRO-232, Project Files Management } \\
\text { HNF-PRO-2778, IRM Application Software System Life Cycle Standards } \\
\text { HNF-PRO-1929, Regqirements Management } \\
\text { HNF-PRO-268, Control of Purchased liems and Services }\end{array}$ & $\begin{array}{l}\text { FSP-WESF-001, Sections } \\
\text { MS-8; MS-9; CM-1; CM- } \\
\text { 6; WM-1 } \\
\text { FSP-WESF-002, sections } \\
11.0 ; 16.1 ; 16.2 \text {. }\end{array}$ \\
\hline $\begin{array}{l}\text { SECTION 5, WORK PROCESSES } \\
\text { - Work Proces Documents } \\
\text { - Spocial Process } \\
\text { - Identification and Control of ltems } \\
\text { - Handling, Shipping, and Storing } \\
\text { - Process Mooitoring or Data Collection Instruments } \\
\text { - Control of Computer Software }\end{array}$ & 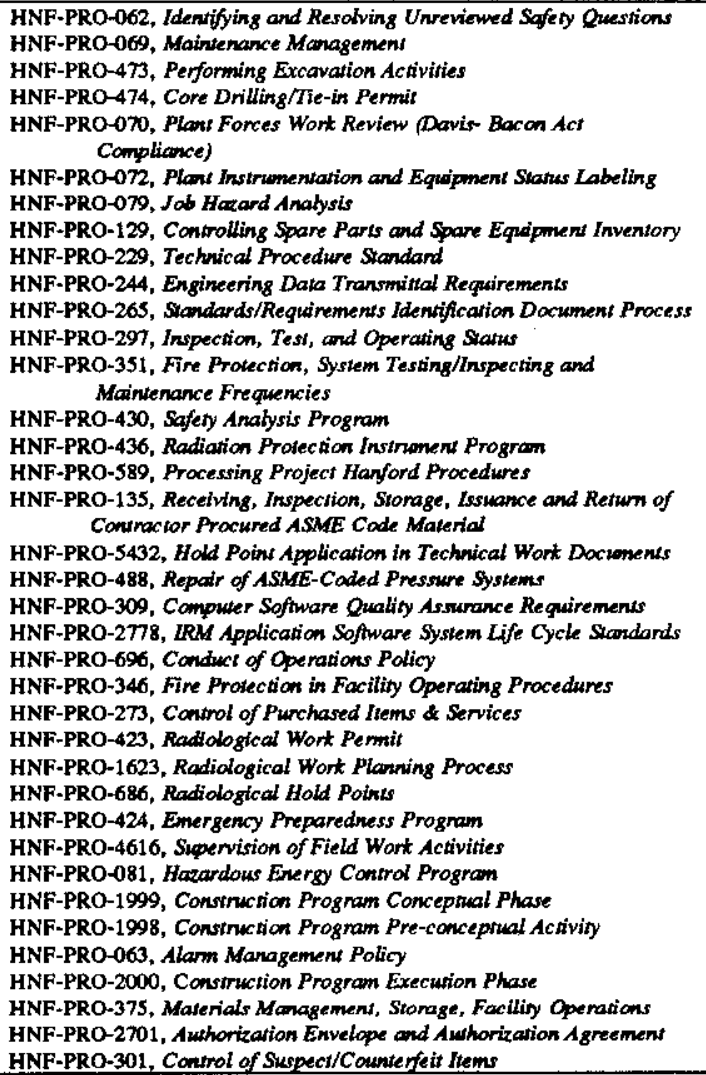 & $\begin{array}{l}\text { SP-WBSF-001, } \\
\text { Soctions MN-1; MN-2; } \\
\text { CM-1; CM-2; CM-3; CM- } \\
\text { 4; CM-5; CM-6; MS-4; } \\
\text { MS-10; MS-12; NS-1; NS- } \\
\text { 2; OP-1; RP-2; RP-3; RP- } \\
\text { 4; RP-6; RP-7. } \\
\text { FSP-WESF-0893 } \\
\text { FSP-WESF-1217 } \\
\text { FSP-WESF-002. }\end{array}$ \\
\hline $\begin{array}{l}\text { SECTION 6, DESIGN } \\
\text { - Design Input } \\
\text { - Design Process } \\
\text { - Design Verification } \\
\text { - Design Changea } \\
\end{array}$ & 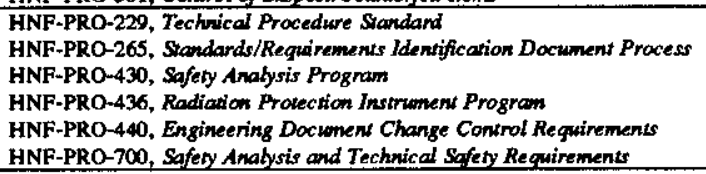 & $\begin{array}{l}\text { FSP-WESF-001, Section } \\
\text { MN-2, CM-1, EN-1 }\end{array}$ \\
\hline
\end{tabular}


HNF-SD-WM-QAPP-037, REV 1

\begin{tabular}{|c|c|c|}
\hline \multicolumn{3}{|c|}{$\begin{array}{l}\text { WESF } \\
\text { HNF-MP-599, PHMC QAPD IMPLEMENTATION MATRIX } \\
\text { MARCH 2, } 2000\end{array}$} \\
\hline \multirow{2}{*}{$\begin{array}{l}\text { PROJECT HANFORD QAPD } \\
\text { PART } 2\end{array}$} & \multicolumn{2}{|l|}{ IMPLEMENTING PROCEDURES } \\
\hline & $\begin{array}{l}\text { PHMC-WIDE } \\
\text { PROCEDURES }\end{array}$ & $\begin{array}{l}\text { CONTRACTOR } \\
\text { PROCEDURES } \\
\end{array}$ \\
\hline $\begin{array}{l}\text { SECTION 6, DESIGN (continued) } \\
\text { - Design Input } \\
\text { - Design Process } \\
\text { - Design Verification } \\
\text { - Design Changes } \\
\text { - Design Documentation and Recorda } \\
\text { - Computer Software } \\
\text { - Design Documentation and Records }\end{array}$ & 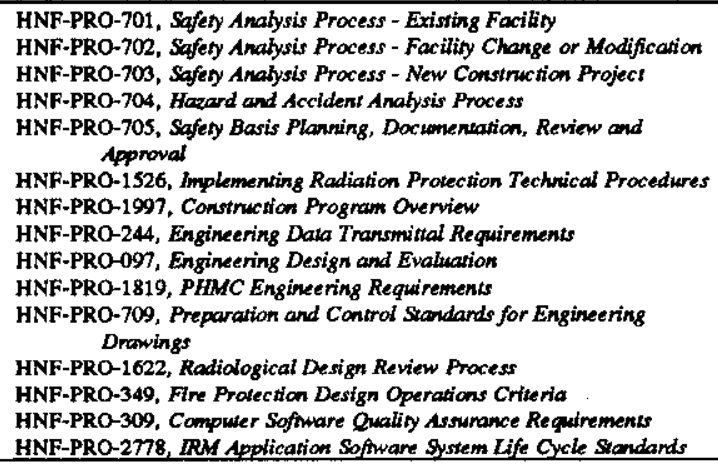 & \\
\hline $\begin{array}{l}\text { SECTION 7, PROCUREMENT } \\
\text { - Procurement Planning } \\
\text { - Content of Procurement Documents } \\
\text { - Supplier Evaluation and Seloction } \\
\text { - Control of Supplier Nonccofformance } \\
\text { - Acceptance of Items and Services } \\
\text { - Commercial Grade Items } \\
\text { - Control of Supplier-Generated Document } \\
\text { - Control of Suspect/Counterfeit Items }\end{array}$ & 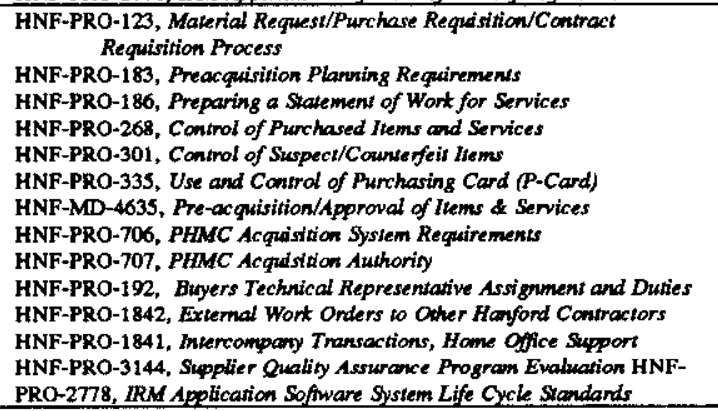 & $\begin{array}{l}\text { FSP-WESF-001, } \\
\text { MN-1 }\end{array}$ \\
\hline $\begin{array}{l}\text { SECTION 8, INSPECTION AND ACCEPTANCE } \\
\text { TESTING } \\
\text { - Inspection and Acceptance Teating Planning } \\
\text { - Inepection and Acceptance Teating Procens } \\
\text { - Inspection and Acceptance Teating Resulta } \\
\text { - Inspection and Acceptance Teuting Status } \\
\text { - Calibrition of Mesuring and Teat Equipment }\end{array}$ & $\begin{array}{l}\text { HNF-PRO-263, Qualification and Certification of } \\
\text { Inspection and Test Personnel } \\
\text { HNF-PRO-268, Control of Purchased liems and Services } \\
\text { HNF-PRO-283, Control of Inspections } \\
\text { HNF-PRO-286, Test Control } \\
\text { HNF-PRO-297, Inspection, Test, and Operating Status } \\
\text { HNF-PRO-490, Control of Measwing and Test Equipment } \\
\text { HNF-PRO-1607, Visual Weld Inspection } \\
\text { HNF-PRO-489, Thind-Party Inspections } \\
\text { HNF-PRO-436, Radiation Protection Instronent Program } \\
\text { HNF-PRO-301, Control of Suspeci/Counterfeit leems }\end{array}$ & $\begin{array}{l}\text { FSP-WESF-001 Sections } \\
\text { CM-2; MN-2; RP-4 }\end{array}$ \\
\hline $\begin{array}{l}\text { SECTION 9, MANAGEMIENT ASSESSMENT } \\
\text { - Management Assesuments } \\
\text { - Corroctive Action } \\
\end{array}$ & $\begin{array}{l}\text { HNF-PRO-052, Corrective Action Monagement } \\
\text { HNF-PRO-246, Management Assessment } \\
\text { HNF-PRO-653, Deficiency Tracking System } \\
\text { HNF-PRO-319, Radiation Protecrion Self-Assessments }\end{array}$ & $\begin{array}{l}\text { FSP-WESF-001, Section } \\
\text { QA-2 }\end{array}$ \\
\hline
\end{tabular}

